\title{
PELATIHAN PEMBUATAN PRODUK HIASAN DENGAN LIMBAH KAIN PERCA DI KELURAHAN PANGKALAN JATI KOTA DEPOK
}

\author{
Nani Muliyani ${ }^{1}$, Lies Sunarmintyastuti ${ }^{2}$, Berta Dian Theodora ${ }^{3}$, Siti Marti’ah $^{4}$ \\ Informatika, Fakultas Teknik dan Ilmu Komputer, Universitas Indraprasta PGRI
}

\begin{abstract}
Abstrak
Negara Indonesia memiliki potensi berupa industri kreatif, salah satunya produk kerajian di Indonesia memiliki potensi besar untuk berkembang. Pembicaraan tentang produk hiasan dapat ditemukan diberbagai tempat disekitar kita. Bahan baku dari produk ini dapat berasal dari bahan baku baru ataupun bahan baku bekas (limbah). Pengertian limbah adalah sisa suatu usaha atau kegiatan. Industri Garment menghasilkan limbah berupa kain perca. Limbah ini dapat memiliki nilai ekonomis dengan cara membuatnya menjadi bunga-bunga cantik lalu dirangkai menjadi karangan bunga (buket) atau menjadi bros berbentuk bunga. Berdasarkan pengamatan sementara diketahui bahwa ibu-ibu warga RT 01 RW 01 Kelurahan Pangkalan Jati, Kota Depok belum pernah melakukan kegiatan kerajinan tangan berbahan dasar kain perca untuk membuat berbagai aplikasi atau hiasan. Tujuan pengabdian kepada masyarakat untuk memberikan pelatihan keterampilan pembuatan produk dengan menggunakan bahan baku limbah kain perca menjadi produk bernilai ekonomis dan memberikan pengetahuan bagaimana menentukan harga jual produk. Kegiatan yang dilakukan bersama warga ibu-ibu RT 01 RW 01 kelurahan Pangkalan Jati kota Depok, peserta antusias mempelajari dan memperhatikan serta mengikuti pelatihan dan praktek pembuatan karangan bunga (buket) dan bros bunga kecil yang diberikan. Peserta menyadari bahwa hasil yang diperoleh dari kreatifitas, inovasi dari pemanfaatan limbah kain perca yang dapat diubah bentuknya menjadi karya karangan bunga (buket) dan bros bunga unik dan berkualitas serta bernilai jual.
\end{abstract}

Kata kunci : Hiasan, Limbah, Kain Perca

\begin{abstract}
Abstact
One of the potentials possessed by Indonesia is the creative industry. Crafts products in Indonesia have great potential to develop. Talks about decorative products can be found in various places around us. The raw materials of this product can come from new raw materials or waste materials. Definition of waste is the remainder of a business or activity. The Garment Industry produces patchwork waste. This waste can have economic value by making it into beautiful flowers and then arranged into a bouquet or into a flower shaped brooch. Based on the interim observations it is known that the residents of RT 01 RW 01 in Pangkalan Jati Village, Depok City have never done patchwork-based handicraft activities to make various applications or decorations. The purpose of community service is to provide product skills training by using patchwork waste raw materials to become economically valuable products and provide knowledge on how to determine product selling prices. The activity was carried out together with the residents of RT 01 RW 01 in Pangkalan Jati Village, Depok City, where participants enthusiastically studied and paid attention and participated in the training and practice of making bouquets and small flower brooches. Participants realized that the results obtained from creativity, innovations from the use of patchwork waste that could be transformed into bouquets and unique flower brooches with quality and value for sale.
\end{abstract}

Keywords: Ornaments, Waste, Patchwork

Correspondence author: Nani Mulyani, nanimuliyani.wangsa@gmail.com, Indonesia 


\section{PENDAHULUAN}

Negara Indonesia memiliki potensi berupa industri kreatif. Produk kerajinan dengan memanfaatkan ketrampilan tangan dan prosesnya membutuhkan waktu lama serta hasilnya yang terbatas, juga termasuk dalam industri kreatif yang menjadi unggulan pengembangan ekonomi kreatif 2025 oleh Departemen Perdagangan RI (2008). Produk kerajian di Indonesia memiliki potensi besar untuk berkembang. Kerajinan menampilkan keindahan dan keunikan yang dihasilkan oleh ketrampilan tangan dari proses pembuatannya. Salah satu produk kerajinan yang dapat dikembangkan adalah produk hiasan.

Pembicaraan tentang produk hiasan dapat ditemukan diberbagai tempat disekitar kita. Sebagai contoh hiasan didalam rumah disebut estetis interior, hiasan diluar rumah disebut estetis eksterior dan produk hiasan yang dipakai manusia disebut perhiasan. Produk hiasan adalah produk yang memiliki nilai hias. Pada dasarnya setiap produk hias memiliki nilai estetik bahkan kadang-kandang memiliki nilai fungsi.

Berdasarkan pengamatan sementara diketahui bahwa ibu-ibu warga RT 01 RW 01 Kelurahan Pangkalan Jati, Kota Depok belum pernah melakukan kegiatan kerajinan tangan berbahan dasar kain perca untuk membuat berbagai aplikasi atau hiasan. Oleh sebab itu ibu-ibu warga RT 01 RW01 Kelurahan Pangkalan Jati, Kota Depok akan diberikan pelatihan ketrampilan kerajinan tangan dan wawasan secara teori dan praktek oleh Dosen dari Universitas Indraprasta PGRI dalam program pengabdian masyarakat. Program tersebut memperkenalkan bagaimana memanfaatkan limbah dari kain perca menjadi hasil produk hiasan, agar supaya mempunyai nilai ekonomis dan bagaimana menetapkan harga jual suatu produk industri kreatif tersebut. Dalam hal ini Dosen dari Universitas Indraprasta memberikan pelajaran dengan melaksanakan praktek untuk membuat karangan bunga (buket) dan bros bunga kecil yang cantik dari bahan limbah kain perca.

Dari pemberian bekal diharapkan warga akan termotivasi untuk memperoleh keberanian dan mendapatkan gambaran secara jelas bagaimana dapat melaksanakan suatu kegiatan atau usaha agar dapat menghasilkan, memperoleh keuntungan serta menghindari kerugian. Mendapatkan wawasan, kesadaran arti pentingnya berwirausaha. Memberikan kesadaran kepada warga untuk mencintai lingkungan dengan pemanfaatan limbah atau barang bekas

\section{METODE PELAKSANAAN}

limbah adalah sisa suatu usaha atau kegiatan. Sedangkan kegiatan yang menghasilkan limbah dapat dibedakan menjadi dua yaitu kegiatan rumah tangga dan kegiatan industri. Sesuai dengan tujuan semula pada saat ini berfokus pada limbah yang dihasilkan dari Industri Garment yaitu yang berupa kain perca. Limbah kain perca dapat menjadi nilai ekonomis dan bermanfaat dengan sentuhan tangan. Dari limbah kain perca dapat dibuat menjadi bunga-bunga cantik yang dapat dimanfaatkan sebagai karangan bunga (buket) yang cantik dan tahan lama jika dibandingkan dengan buket bunga asli. Disamping itu dapat juga dibuat bros bunga kecil dan cantik.

Berdasarkan pendahuluan maka tujuan dari kegiatan masyarakat ini adalah : Kegiatan pengabdian masyarakat bertujuan untuk memberikan pengetahuan dan pelatihan ketrampilan kepada ibu-ibu warga RT 01 RW 01 Kelurahan Pangkalan Jati, Kota Depok dalam memanfaatkan limbah kain perca sebagai bahan baku untuk 
membuat produk yang mempunyai nilai ekonomis dan sekaligus dapat menjaga lingkungan dengan memanfaatkan limbah yang ada dan memberikan pengetahuan bagaimana menentukan harga jual produk hiasan yang dibuat dari bahan baku limbah kain perca.

Pengabdian masyarakat dilakukan dengan memberikan pelatihan pembuatan produk bunga (gambar 1) dan produk hiasan bros bunga kecil (gambar 2) dengan menggunakan bahan baku utama yaitu limbah kain perca. Dalam kegiatan Pengabdian Masyarakat, tim membagikan materi yang akan dijadikan bahan pembelajaran. Materi yang dibagikan berupa selebaran (Hand Out) yang dikembangkan sendiri oleh tim abdimas sesuai dengan kompetensi masing-masing anggota. Untuk metode penyampaian materi dilaksanakan dengan cara memberikan tutorial. Dalam kegiatan pelatihan metode yang digunakan tim abdimas adalah drill and practice dimana peserta mendengarkan arahan dari narasumber dan langsung mempraktekan. Disamping itu memberikan bahan kain perca, jarum, benang, gunting, lem tembak, jarum pentul, jarum jahit, tusuk kawat, peniti kecil, lilin untuk praktek pembuatan karangan bunga (buket) dan bros bunga kecil (gambar 3).

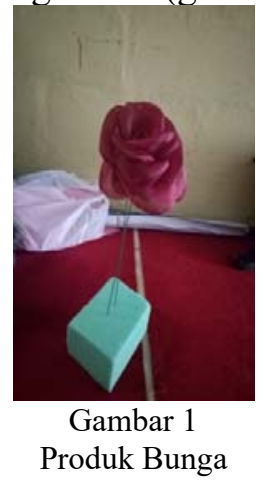

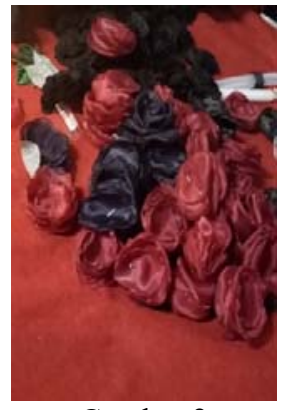

Gambar 2 Produk Hiasan Bros

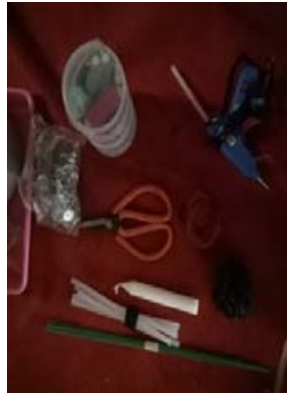

Gambar 3

Peralatan yang dipakai

Metode yang akan dilaksanakan dalam kegiatan ini adalah metode pendekatan pembelajaran yang berorientasi atau berpusat pada warga. Hal tersebut untuk menambah pemahaman teori dan praktek secara nyata pada warga baik hard skill maupun soft skill dalam pengembangkan dirinya sendiri untuk lebih mandiri, lebih semangat, lebih kreatif dalam pemanfaatan limbah kain perca untuk dibuat produk karangan bunga (buket) dan bros bunga kecil yang bernilai ekonomis atau mempunyai nilai jual.

Adapun teknik yang dilakukan di dalam pelatihan ini adalah:

1. Memberikan selayang pandang teori Kewirausahaan dan memberikan motivasi agar warga memiliki kesadaran arti pentingnya berwirausaha.

2. Memberikan penjelasan, bagaimana menghitung, menentukan harga jual produk karangan bunga (buket) dan produk hiasan bros bunga kecil dengan bahan baku dari limbah kain perca.

3. Pelatihan dan Praktek pembuatan kerajinan tangan produk karangan bunga (buket) dan produk hiasan bros bunga kecil dari bahan baku limbah kain perca.

\section{HASIL DAN PEMBAHASAN}

Bagaimana supaya Industri Kreatif ini cepat tumbuh dan berkembang menjadi faktor pendukung pengenalan minat terhadap Industri Kreatif secara luas kepada 
masyarakat secara berkelanjutan dan langsung ke masyarakat. Namun pembuat kerajinan rumahan selalu mengalami kesulitan dalam menentukan harga dari hasil karyanya. Dalam menghasilkan suatu karya, dibutuhkan landasan teori dan praktek, agar dapat menghasilkan suatu karya yang indah bermakna, mempunyai fungsi, mempunyai nilai ekonomis. Oleh sebab itu penilaiannya harus efektif dan efisien. Nilai Efektif berhubungan dengan mutu, sedangkan efisien berhubungan dengan biaya. Disamping itu diperlukan teori atau cara untuk menentukan harga jual, agar supaya dapat memberikan keuntungan secara nyata dan akan lebih bermanfaat. Oleh sebab itu untuk menentukan harga jual diperlukan suatu pendekatan atau strategi, sehingga dari perhitungan ini dapat memproyeksikan dan mengelola laba atau keuntungan usaha yang diinginkan setiap bulan atau setiap tahun.

Secara umum sebelum menentukan harga jual kepada konsumen, seharusnya perlu memisahkan dua komponen biaya dalam usaha, yakni biaya tetap dan biaya variabel. Sebagai contoh biaya listrik, telepon dan gaji pegawai termasuk biaya tetap. Artinya beban biaya yang tidak terpengaruh volume produksi atau volume penjualan. Sedangkan biaya variabel adalah biaya yang nilainya tergantung pada volume produksi atau volume penjualan misalnya biaya bahan baku, biaya entertainment (kalau ada), biaya proses produksi, biaya transportasi. Menurut pengalaman beberapa pengusaha mengatakan bahwa porsi biaya tetap tidak lebih dari $50 \%$ nilai penjualan produk. Sedangkan total pengeluaran rutin perbulan berkisar dari $60 \%-70 \%$ dari omzet yang terjual. Setelah menentukan biaya-biaya yang dikeluarkan selanjutnya diperlukan menetapkan harga pokok (biaya untuk mendapatkan barang tersebut). Proses berikutnya harga pokok ditambah dengan biaya lain-lain dan keuntungan yang diharapkan, maka keluarlah harga jual. Tetapi pendekatan harga pokok produksi seperti penjelasan tersebut tidak baku. Jika produk sulit ditemukan di pasaran sementara permintaan tinggi pengusaha dapat mematok harga jual tinggi. Sebaliknya kalau banyak pesaing perlu menetapkan harga rendah. Untuk mendapatkan harga jual harus dipastikan dengan melakukan riset pasar terhadap minat dan selera pembeli.

Misalnya untuk menetapkan harga produk/harga pokok setelah menghitung biaya produksi diperlukan melihat harga pesaing. Seharusnya harga jual yang ditentukan harus hampir sama dengan harga jual pesaing untuk produk yang sejenis. Namun boleh menetapkan harga jual sedikit lebih tinggi dari pesaing, kalau lokasi berjualan lebih strategis, lebih tinggi mutunya atau lebih memiliki pelanggan tetap. Jika tidak ada keunggulan diperlukan menetapkan harga yang sedikit lebih rendah. Meskipun menetapkan harga jual lebih rendah seharusnya sudah termasuk perhitungkan keuntungannya. Kemungkinan berkisar 10\% sampai dengan 20\% dari harga pokok. Suatu usaha yang belum memiliki keunggulan penetapan harga jual menjadi faktor yang penting. Disamping itu dapat memanfaatkan faktor harga untuk mendatangkan pelanggan dengan cara memberi potongan harga untuk produk tertentu. Tujuannya agar pelanggan berdatangan atau tertarik beralih ke produk atau jasa yang ditawarkan.

Hasil dan luaran yang dicapai dalam pelaksanaan kegiatan pengabdian kepada masyarakat ini adalah sebagai berikut:

1. Kegiatan Pengabdian kepada Masyarakat ini diharapkan mampu memberikan pengetahuan, wawasan peluang usaha dan gambaran secara menyeluruh bahwa bahan limbah dari kain perca dapat mempunyai nilai ekonomis dan bermanfaat khususnya bagi para ibu rumah tangga untuk mengisi waktu luang dapat membantu dan menambah masukan bagi ekonomi keluarga. 
2. Memberikan kesadaran kepada masyarakat khususnya para ibu rumah tangga untuk mempersiapkan diri secara mental, fisik dengan bermodal ketrampilan yang dimiliki dapat menumbuhkan minat untuk berwirausaha.

3. Menumbuhkan sikap kreatif, inovatif dan mampu mengelola hasil yang diperolehnya, yang periode selanjutnya mulai berbisnis berskala kecil kepada masyarakat khususnya untuk para ibu rumah tangga.

4. Memberikan ilmu pengetahuan dan pemahaman tentang kewirausahaan khususnya pemanfaatan peluang untuk berbisnis dan gambaran bagaimana pengelolaan hasilnya.

5. Dengan kegiatan pelatihan ini, secara langsung membantu pemerintah dalam mengurangi pengangguran dengan memberikan bekal kepada masyarakat khususnya para ibu rumah tangga untuk memanfaatkan waktu luang dengan mempergunakan bahan limbah menjadi bernilai ekonomis untuk dijual dan dapat membantu ekonomi keluarga agar lebih sejahtera dalam kehidupannya.

Kegiatan pengabdian kepada masyarakat yang dilaksanakan adalah berjudul "Pelatihan Pembuatan Produk Hiasan Dengan Limbah Kain Perca di Kelurahan Pangkalan Jati Kota Depok". Hal ini diharapkan bermanfaat bagi masyarakat khususnya bagi para ibu rumah tangga. Sedangkan harapan dari pelaksanaan pengabdian masyarakat ini adalah untuk mengurangi pengangguran dengan memberikan wawasan, pelatihan dan ketrampilan kepada masyarakat khususnya bagi para ibu rumah tangga, pada prinsipnya jika ada peluang dan waktu luang dapat dipergunakan untuk kegiatan yang berguna dan bernilai ekonomis untuk membantu perekonomian keluarga. Hasil dari pemberian pelatihan ini dapat memberikan tambahan bekal ilmu pengetahuan yang dapat dipertimbangkan untuk bermanfaat bagi masyarakat khususnya bagi para ibu rumah tangga.

Dalam pelaksanaan pelatihan khususnya dalam pembuatan karangan bunga (buket) dan perhiasan bros bunga kecil diberikan contoh dan dipraktikan, dibimbing dengan langkah-langkah secara berurutan satu persatu agar dapat memberikan gambaran secara nyata kepada para ibu-ibu.

Didalam pemberian materi diberikan waktu untuk bertanya dan berdiskusi dengan para Ibu - ibu rumah tangga RT 01 RW 01 kelurahan Pangkalan Jati Depok. Hal itu bertujuan memberikan kesempatan untuk memperdalam dan memberikan semangat serta menggali minat kepada para ibu-ibu rumah tangga untuk belajar dan memanfaatkan waktu luang untuk berwirausaha sesuai minat.

\section{SIMPULAN}

Pelaksanaan pelatihan dan pembelajaran penentuan harga jual produk hiasan dari limbah kain perca sebagai salah satu hasil produk Industri Kreatif pada ibu-ibu warga RT 01 RW 01 Kelurahan Pangkalan Jati Kota Depok menghasilkan :

1. Mendapatkan wawasan, kesadaran arti pentingnya berwirausaha.

2. Memberikan kesadaran kepada warga untuk mencintai lingkungan dengan pemanfaatan limbah atau barang bekas

3. Menumbuhkan kreativitas dan inovasi untuk pemanfaatan bahan limbah kain perca diubah menjadi barang yang bernilai ekonomis (bernilai jual)

4. Warga dapat siap kerja dan lebih kreatif untuk memanfaatkan limbah dari kain perca sebagai bahan baku pembuatan karangan bunga (buket) dan produk hiasan bros bunga kecil. 
5. Warga mampu menghitung dan menetapkan harga jual secara sederhana untuk hasil karangan bunga dan produk hiasan bros bunga kecil dari limbah kain perca sebagai bahan baku.

6. Warga mampu menghitung dan memperkirakan secara sederhana hasil pendapatan serta laba dan rugi hasil produk karangan bunga (buket) dan produk hiasan bros bunga kecil dari limbah kain perca dalam jangka pendek maupun jangka panjang.

7. Memberikan kesadaran bahwa hasil yang diperoleh dari kreatifitas, inovasi dari pemanfaatan limbah kain perca yang dapat diubah bentuknya menjadi karya karangan bunga ( buket ) dan bros bunga unik dan berkualitas dapat bernilai jual, untuk langkah selanjutnya dapat dipasarkan melalui pameran atau melalui media online sebagai penambahan pendapatan untuk membantu keluarga.

\section{DAFTAR PUSTAKA}

Alma, B. (2005). Kewirausahaan, Bandung : Alfabeta

Danuhadimedjo. R.D. (2011). Kewiraswastaan dan Pembangunan.Badung : penerbit Alfabeta

Mudjiarto, A.W. (2008). Kewirausahaan Motivasi dan Prestasi Dalam Karier Wirausaha.Jakarta: Penerbit UIEU -University Press.

Riyanti, D.B.P. (2002). Factor Influencing The of Small-scale entrepreneur in Indonesia. Jakarta: Admajaya Indonesia catholic University.

Suryana. (2013). Kewirausahaan kiat dan proses menuju sukses edisi 4. Jakarta : Salemba Empat

Zimmerer, T.W., dan Scarborough, N.M. (2005). Pengantar Kewirausahaan dan Manajemen Bisnis Kecil. Jakarta : Mitra Wacana Media. 